This is the final peer-reviewed accepted manuscript of an article which has been published in final form in

Land Use Policy Volume 70, January 2018, Pages 654-665, https://doi.org/10.1016/j.landusepol.2017.10.050

3

\title{
Remittance inflow and smallholder farming practices. The case of Moldova
}

\author{
Piras, Simone ${ }^{1}$; Vittuari, Matteo ${ }^{1}$; Möllers, Judith²; Herzfeld, Thomas ${ }^{2,3}$ \\ ${ }^{1}$ Department of Agricultural and Food Sciences, University of Bologna, viale Giuseppe Fanin 50, 40127 Bologna, Italy \\ ${ }^{2}$ Department Agricultural Policy, Leibniz Institute of Agricultural Development in Transition Economies (IAMO), \\ Theodor-Lieser-Straße 2, 06120 Halle (Saale), Germany \\ ${ }^{3}$ Martin-Luther-Universität Halle-Wittenberg, Universitätsplatz 10, 06108 Halle (Saale), Germany
}

\begin{abstract}
In the Republic of Moldova, a large number of households that received land shares after the break-down of the collective farm structure currently focus on semi-subsistence agriculture. Often, one or more members of these households have migrated abroad. This paper aims at assessing the impact of remittances on their agricultural production practices and investments. The authors rely on the rotating panel dataset of the Household Budget Survey for the period 2007-2013, and on an original survey carried out on a sample of 126 households in 2015. To test if remittance recipients replace family labour and self-produced inputs with mechanisation services and purchased inputs, a shadow agricultural wage is estimated. Logistic regressions are used to assess whether the occurrence of investments (land, machinery, or dairy cattle) is more probable in the case of remittance inflow. The results show that recipient households reduce their drudgery by substituting family labour and self-produced seeds and feed with mechanisation services and purchased inputs, without necessarily increasing production efficiency. The relationship between remittances and agricultural investments is very weak or negative. However, qualitative insights demonstrate that many investments (greenhouses, rototillers, walnut orchards, etc.) were possible thanks to remittances. Although most recipients do not invest in agriculture, the minority that does invest has access to remittances.
\end{abstract}

Keywords: smallholders; remittances; investment decisions; farming practices; Republic of Moldova.

\section{Introduction}

In a number of formerly centrally-planned economies, the decollectivisation of agriculture and privatisation of land resulted in agricultural structures dominated by small farms. Romania, Latvia, Lithuania and Moldova, in particular, experienced an increase in the share of agriculture in employment, combined with a growing number of individual farms (Macours and Swinnen, 2005; Swinnen et al., 2005). Many of these smallholders focus on semi-subsistence farming. Indeed, apart from the small size of their plots, which is not enough to provide decent revenue, the shortage of agricultural credit and the unreliability of output markets obstruct the development of viable commercial farms. Furthermore, the lack of non-farm jobs on the rural labour market represents a constraint in pursuing alternative livelihood choices locally. International migration has thus become a widespread strategy, illustrated by the high inflow of remittances. The Republic of Moldova is a prime example of this development pattern. Here, the break-down of collective agriculture generated around 900,000 small family farms within a population of 3.55 million inhabitants (NBS, 2011), while, due to high rates of emigration, in the last decade remittances have accounted for 20-30\% of the GDP (World Bank, 2017). But whether households use this income for consumptive purposes or to invest in and develop their farming businesses remains an open question.

(C) 2018 Elsevier. This manuscript version is made available under the Creative Commons AttributionNonCommercial-NoDerivs (CC BY-NC-ND) 4.0 International License (http://creativecommons.org/licenses/by-nc-nd/4.0/) 1 
The literature on migration and agricultural change focuses either on developing countries in Latin America (Aguilar-Støen et al., 2016; Davis and Lopez-Carr, 2014; Gray, 2009; Gray and Bilsborrow, 2014; Jacoby, 1993; Taylor et al., 2016), Asia (Adams Jr., 1998; Sunam and McCarthy, 2016) and Africa (Adams Jr., 1991), or on emerging countries, primarily China (de Brauw and Rozelle, 2008; Liu et al., 2016; Qin and Liao, 2016; Rozelle et al., 1999). As for Eastern Europe, both the impact of remittances on the overall economy (León-Ledesma and Piracha, 2004), and the relationship between migration and agricultural labour (Macours and Swinnen, 2005), or land use (Baumann et al., 2011) have been investigated. Due to the huge proportions assumed by international migration in Moldova, the impact of remittances on its economy has been assessed in specific studies (Lücke et al., 2009; Pinger, 2010). The relationship between remittances and land use has been looked at by Bolganschi (2011). Based on the results of a qualitative survey and on secondary data, she argues that migration causes farming households to switch towards less labour-demanding production activities, and fosters farm exit, although most emigrants maintain the property of their land. She does not, however, provide an in-depth analysis at to whether remittance inflow generates any change in the agricultural practices of the households who do not exit farming.

Economic theory offers several channels for explaining how migration could affect laboursending rural households. First, abstracting from hidden unemployment, migration of labour force should lead to an increase in the opportunity cost of labour (Singh et al., 1986). Second, remittances can enable households to overcome credit constraints (Stark, 1991). Conditional upon the possibility to hire labour as a compensation for migrated household members, remittances will be invested in productive or non-productive durable assets. The empirical evidence from a range of developing and transition economies is rather mixed. On the one hand, Taylor and Lopez-Feldman (2010) find for Mexicans migrating to the US that the incomes of sending households and their agricultural productivity increase due to remittances. Similarly, using Mexican data, Böhme (2015) finds that accumulated agricultural assets are greater in households receiving international remittances, but cannot find evidence of investment in riskier activities, like livestock husbandry. Furthermore, he shows that investments are subject to a life-cycle, that households with older heads invest less, and that migrant households even disinvest more at later stages of their life cycle than non-migrant households. Differentiating between productive and non-productive assets, and controlling for asset accumulation effect, Chiodi et al. (2012) find evidence that rural Mexican households tend to use remittances to invest in productive assets. On the other hand, using farm household data from Albania, Kilic et al. (2009) find that non-farm income is used to move out of crop production and, for commercial farms, to invest in livestock production. Also, the intensity of arable land use follows an inverted $\mathrm{N}$-shaped curve as rural out-migration increases, due to the concurrent impact of labour shortage and intensified use of fertiliser and pesticide inputs (Liu et al., 2016). Qin and Liao (2016) analyse the relationship between migration, agricultural change and general regional development by qualitatively reviewing twenty case studies from rural China. They find that agricultural production declines in regions with high outmigration and general low economic development, while in more economically developed regions out-migration and agricultural production seem to be positively related. Thus, whether remittances are used for achieving agricultural modernisation depends on the context and, probably, on household-specific characteristics.

This paper aims at assessing the impact of remittances on the production practices of Moldovan smallholders. More specifically, it analyses whether households receiving remittances change their on-farm labour use, and whether they invest at least part of their remittances into agriculture. Differently from previous studies on this country, econometric analyses drawing from a rich database - the database of the Household Budget Survey (HBS) of the National Bureau of 
Statistics of the Republic of Moldova (NBS) for the period 2007-2013 - were carried out, applying (and building on) the methodology developed by Skoufias (1994). A further contribution of this paper relates to the combination of quantitative analyses and qualitative insights from an original survey carried out by one of the authors in spring 2015 (hereafter, "2015-smallholdersurvey"). To avoid endogeneity issues due to common characteristics driving households' decisions related to migration, production, and consumption, here panel data allow for a more consistent modelling of the relationship between remittance inflow, and smallholders' investment decisions. To our knowledge, this is the first study analysing the effect of remittances on agricultural investments in a transition country context. The case of Moldova is particularly relevant due to the paramount role played by family farming in the national economy and society, and to the signing of an Association Agreement between this country and the European Union (EU) in 2014, which is expected to generate interesting opportunities for commercial farmers.

The rest of the paper is structured as follows. Section 2 provides a short background on smallholder agriculture and international migration in Moldova. Section 3 introduces the data and the methodology. Section 4 presents and discusses the results of the econometric analysis, putting them in perspective using the insights from the 2015-smallholder-survey. Section 5 concludes and provides some policy implications.

\section{Smallholder agriculture and international migration in Moldova}

Moldova is a small landlocked country in which agriculture has long been an important economic activity $^{1}$. While a member of the USSR, the country was a net exporter of agro-food products to the rest of the Union (primarily wine, spirits, and fresh products, like fruits and vegetables) ${ }^{2}$ (Gorton and White, 2003). Its agro-industrial complex was dominated by huge collective and State farms: the only form of family agriculture was the small plots allocated to the members of rural households and to urban workers, which accounted for $7 \%$ of the agricultural land. Households were also engaged in animal breeding, producing a large share of the national output of meat, milk, eggs, and sheep wool. Smallholders emerged as a result of the insider privatisation of collective and State farms. Although foreseen in the Land code of 1991, the process of land distribution didn't begin until 1998, when the Parliament passed the National Land Program, and was carried out in the form of "shares".

The portion of privately-owned land grew from around nil to $67 \%$ in 2003. In 2001, over 500,000 individuals had received land shares, and over 200,000 had registered their household as a peasant farm, with an average size of 1.8 hectares. However, the reform overlooked the role of collective and State farms as providers of social services and managers of rural infrastructure (including irrigation systems), which fell into disrepair. Furthermore, in many cases the privatisation process turned into a "grab what you can" at local level (Ibidem: 321). Reformers expected a structure of middle-sized commercial family farms to emerge gradually through market-based

\footnotetext{
${ }^{1}$ All studies on the Republic of Moldova, including this one, focus on the western region of the country (Bessarabia), since eastern Moldova (Transnistria) is not controlled by the national government. The surface of Bessarabia is 30,355 square kilometres and, as of 2017, its population is 3.55 million inhabitants, of whom $57 \%$ live in rural areas (NBS, $2017 \mathrm{c}$ ). The share of territory covered by arable land and permanent crops (64\% in 2014) is one of the largest in the world (World Bank, 2017).

${ }^{2}$ Until 2005, agri-food products and drinks accounted for over 50\% of Moldovan exports, and were still accounting for $33 \%$ in 2016 (NBS, 2017c).

${ }^{3}$ Home gardens and household plots were assigned to the households farming them as "small shares". The land farmed collectively (arable land, orchards and vineyards) was divided into "big shares", whose size and composition were set at the level of municipality based on the local land endowment. Furthermore, "shares of values" of the assets of collective and State farms were created. All workers of these State farms, including pensioners and former workers as of 1 January 1992, were entitled to a share. Furthermore, up to $50 \%$ of the local land was distributed to local residents belonging to certain categories, if none of their family members were eligible (Möllers et al., 2016).
} 
land transactions and investments, thus triggering the economic development of rural areas. Instead, the land market evolved slowly: in ten years, only $2 \%$ of the land changed ownership, the average transaction involving 0.1 hectares (Cimpoieș, 2010). As in other post-Soviet countries, commercial agriculture continues to be dominated by the large corporate farms that succeeded their socialist counterparts (Lerman and Sutton, 2008; Small, 2007).

In the same year that land began to be privatised (1998), Moldova was severely hit by the Russian financial crisis, which lead to the beginning of mass migration. Estimates of the stock of international migrants vary: in 2014, Moldovan diplomatic missions gave a figure of 984,000, up from 505,000 in 2011, while State border authorities gave a figure of 762,000 (IOM, 2016). Since the country is located at the border between the Community of Independent States and the EU, Moldovans migrate in either direction. The common Soviet past reduces the transaction costs of moving to Russia, which has constantly attracted an absolute majority of migrants (550,000 in $2014)$, followed by Italy $(150,000)$ (Ibidem). Migration to Russia tends to be short-term, so that numbers fluctuate more (Lücke et al., 2009). In 2014, limited to temporary migrants $(342,000)$, $72 \%$ came from rural areas, $64 \%$ were male, and the largest age group (35\%) was represented by 25 to 34-year-olds (IOM, 2016). These figures, which had not changed significantly since 2009 , give an idea of the impressive outflow of labour force, accounting for between 25 and $50 \%$ of the active population (Pinger, 2010: 145). Simultaneously, migration resulted in a sizeable inflow of remittances, which peaked at $35 \%$ of the GDP in 2006, and declined to $22 \%$ in 2016, when Moldova was ranked the seventh country in the world by remittances as a share of GDP (World Bank, 2017). During the period studied here, this figure ranged from $34 \%$ in 2007 , to $27 \%$ in 2013 (Ibidem). Of special relevance for the analysis at hand is that remittances have always accounted for around twice the share of family income in rural areas than in cities (23\% vs. $12 \%$ in 2016) (NBS, 2017c).

Despite migration, $94 \%$ of the almost 900,000 family farms (not necessarily registered) detected by the most recent Agricultural Census in 2011 were active (NBS, 2011). This corresponds to one active family farm for every 4.2 inhabitants: the highest incidence among European and Central Asian countries ${ }^{4}$. These family farms were found to have an average size of 1.1 hectares, and make up $43 \%$ of the total agricultural land (NBS, 2011): a much larger share than in Russia or Ukraine, where, in 2008, corporate farms accounted for around $80 \%$ of the total land (Lerman and Sutton, 2008). In 2016, agriculture and related activities produced 12\% of the GDP, while agricultural employment stood at $34 \%$ (NBS, 2017c). Considering that most land recipients did not register their households as farms, and many pensioners cultivate their land, the real numbers are probably much higher. The prevalence of informal agricultural labour can also explain why the share of active population in rural areas was as low as $41 \%$ in 2016 (Ibidem).

Based on the Agricultural Census of 2011, a large majority of Moldovan family farms $(86 \%)$ focus on subsistence production. Less than $9 \%$ sell over half of their output. Farms are small (71\% have a surface area below one hectare, and $99.7 \%$ below ten hectares) and operate with rather old machinery, if at all (e.g., one tractor for every 54 farms, of which $83 \%$ are older than 10 years). Only $0.7 \%$ of the land farmed by family farms is irrigated. Furthermore, family farms rely almost exclusively on family labour ( $81 \%$ of 1.6 million working persons), or on relatives $(17 \%)$. Finally, only $0.1 \%$ of them keep books ${ }^{5}$. Nevertheless, they are more efficient and productive than corporate farms (Lerman and Sutton, 2008: 100): since 1999, their total yearly production at national level has continued to surpass that of the latter (which farm more land) by 1.5 to 2.3 times (NBS, 2017c). Despite this efficiency, family farms face tight credit constraints,

\footnotetext{
${ }^{4}$ Authors' elaboration on data from FAO (2014), and the Moldovan Agricultural Census (NBS, 2011).

${ }^{5}$ Authors' elaboration on data from the Moldovan Agricultural Census (NBS, 2011).
} 
which prevent them from modernising and turning into viable businesses to support future generations. This situation is due to three main reasons: they lack collateral apart from their land, as banks tend to formulate excessive requests (or undervalue their assets); the supply is limited almost exclusively to short-term loans; and there is a lack of instruments facilitating access to credit, such as guarantee funds (Moroz et al., 2015). In 2011, only $0.1 \%$ of these farms received a bank loan, $7 \%$ obtained State subsidies, and less than $1 \%$ had access to other types of financing ${ }^{6}$.

The agricultural sector is a cornerstone of the government's National Development Strategy Moldova 2020, approved in 2012. The general goal of the strategy is to ensure sustainable growth, and improve living conditions in rural areas by increasing "competitiveness and productivity" (FAO, 2012: 22). In the meanwhile, in 2014, the international framework within which Moldova elaborates its rural development policy underwent relevant changes, as its government and the EU signed an Association Agreement (which also includes a Deep and Comprehensive Free Trade Agreement). Much like in other sectors, agricultural policies were also linked to the general goal of EU integration. This is expected to translate into new opportunities and constraints for smallholders, as the EU-like many other international and State-based development agencies active in the country-foresees financial assistance for the producers interested in farm modernisation (e.g., for conforming to food quality and safety standards) (EU, 2014). Understanding the relationship between remittances and agriculture among smallholders can thus contribute to the success of the ongoing rural development measures.

\section{Data and methods}

\subsection{Data}

Two types of data were used: the results of the 2015-smallholder-survey and the database of the Moldovan HBS for the period 2007-2013.

The database of the 2015-smallholder-survey provides an explanatory framework, and makes it possible to identify smallholders' motivations, as well as relationships that are not detectable by means of purely quantitative data. This survey was implemented by a two-person team (a man and a woman) using a structured questionnaire, which was read to an adult member of the households (or to a married couple) in face-to-face interviews. The population of reference consisted of farming households, defined as households cultivating some land and obtaining a nonzero farm income. Participation was voluntary: respondents were identified using snowball sampling, while interviewers controlled for the distribution of two stratifying variables (farm size and age of the household head), which were kept in line with the Agricultural Census (NBS, 2011). The final sample size was $126^{7}$. The period of reference for the answers was either the 12 months before the interview, or the previous agricultural year (November 2013 to October 2014). All monetary values were registered in current (2015) Moldovan Lei (singular: Leu, MDL), and were then converted to EUR, using the 2015 exchange rate, for the purpose of presenting them in this paper $^{8}$.

Within the sample, farm sizes range from 0.04 to 38.50 hectares. Excluding three farms of more than ten hectares, which would not be classified as "small" by the NBS (2017a) and represent clear outliers, the average size is 1.60 hectares, compared to 1.07 in the Agricultural Census. The average age of the household head is 56.5 years, compared to 53.1 in the Agricultural Census.

\footnotetext{
${ }^{6}$ See previous footnote.

${ }^{7}$ A simple random sample of 126 households from a population of 898,768 returns a confidence interval of $\pm 8.7 \%$ at a confidence level of $95 \%$, or of $\pm 11.5 \%$ at a confidence level of $99 \%$. Due to stratification, the actual error margin is likely to be narrower.

${ }^{8}$ In 2015, the average official exchange rate was 20.8980 MDL/EUR (0.0479 EUR/MDL).
} 
218 An absolute majority of interviews was conducted in the districts of Orhei and Telenești, along 219 the Răut River Valley or in the surrounding hills. These districts occupy a midway position between the capital and the periphery of the country; therefore, their agsicultural sector is affected neither by excessive closeness to the former, nor by extreme isolation. To improve sample representativeness, 20 interviews were taken in three districts which present specific conditions: Briceni, the northernmost of the country; Găgăuzia, a remote southern region inhabited by a Turkish-speaking minority; and Chișinău city-district, affected by the spill-overs of the large market of the capital.

Furthermore, semi-structured qualitative interviews were carried out with a rural development manager of the EU Delegation in Chișinău, with the accountant of a village-based association granting short-term loans to smallholders, and with two village-based land registry officers.

The second database is the rotating panel database of the HBS. The HBS aims at determining people's life levels by registering household incomes, expenditures, consumption, living conditions, and related variables (NBS, 2017b). The sampling unit is the household, and the population of reference is all people residing in Moldova outside Transnistria. Sampling follows a twostage procedure: after dividing the country into primary sampling units representing big cities, small towns, or villages, a group of households from each unit is selected. Weights are included to weigh every household according to the size of its unit. Every month, the NBS selects 814 households which must register their incomes and expenditures along a given period (the month of the interview and the last 12 months for remittances and farm income, the last two weeks for expenditures and self-consumed farm products). Monthly data aim at obtaining representative samples on a quarterly or yearly basis. In 2007-2013, yearly sample sizes ranged from a maximum of 6,133 units in 2008 to a minimum of 5,082 in 2013, for a total of 39,414 over the entire period.

Around half of the households taking part in the HBS (from 3,012 in 2007, to 2,437 in 2013 , for a total of 18,804 single observations) are included in a panel study based on atation scheme. They are interviewed up to four times, once every 12 months. For most panel households, less than four observations are available in the period 2007-2013, since they entered the study either before 2007, or after 2010. This time span is not long enough to model phenomena like farm exit, but allows for changes in other key variables to be observed.

The HBS does not focus exclusively on farming households. Therefore, only households earning farm income (either in kind or in money) were selected. Choosing an appropriate definition of "farming household" was not trivial and this one was selected for its inclusiveness, allowing for the detection of a larger spectrum of situations and diverse dynamics. Indeed, while the households obtaining over half of their income from farming are few, agriculture represents an important income source and life activity for many more. The sample size resulting from this definition is 30,119. The number of households decreases gradually, from 4,627 in 2007, to 3,995 in 2013. Of these, 14,503 are panel observations but, for 2,158 households, only one observation is available.

Remittance-recipient households were defined as households receiving money from abroad, regardless of the amount or the sending person (a member of the family, a relative, or a friend). Indeed, the latter information is not available in the database, and the variable indicating whether a specific household member was missing is almost empty. No household in any year reported receiving in-kind remittances, so the sum is made up of monetary transfers only. Internal remittances from non-household members are included within a residual income aggregate, and could not be extracted; furthermore, this aggregate is much smaller than international remittances 
(88 EUR vs. 364 EUR on average for the entire population), and is rarely worth over 600 EUR (10,000 MDL). Hence, it can barely have a relevant impact on agricultural practices and investments. Based on this definition, 7,871 farming households (26\%) are recipients, while 22,248 (74\%) are not. Among panel households for whom more than one observation is available, 3,251 are recipients, while 9,094 are not.

Within the HBS database, monetary values are expressed in current MDL. Before carrying out the econometric analysis, they were deflated to obtain constant 2007 prices. For the purpose of presenting them in this paper, they were converted into EUR using the 2007 exchange rate ${ }^{9}$. The 2015-smallholder-survey and the HBS will be analysed in parallel. Indeed, the two samples are easily comparable: first, the definition of the farming household is the same; second, as already mentioned, the districts covered by the 2015 -smallholder-survey represent the country well.

\subsection{Methodology}

The econometric analysis presented here relies on HBS data for the years 2007 to 2013. All equations were estimated using pooled time-series and cross-section data (like in Skoufias, 1994), ignoring sample weights to avoid mixing them (as suggested by Signoret, 2003).

Before assessing if remittances have an impact on production and investment behaviours, the differences between recipient and non-recipient farming households in terms of demographics and other variables were tested by means of a logit regression (where the dependent variable was a dummy turning one if the family received remittances, zero otherwise), and through quantile regressions estimated among recipients only (using the median, the third quartile, and the $90^{\text {th }}$ percentile, respectively). Based on these estimates, variables for matching recipient and non-recipient households were identified.

To assess whether recipient households tend to replace family labour and self-produced inputs with services and purchased inputs, the shadow value of family labour was calculated. The first step consisted in estimating agricultural production functions.

Four Cobb-Douglas-shaped production functions were estimated: two with male, female and child labour separately (like in Skoufias, 1994; Le, 2009), and two with total family labour. For each setup, an equation was estimated using generalised two-stage least square random-effects ${ }^{10}$, and another using the single-equation generalised method of moments (Jacoby, 1993; Le, 2009), both with instrumental variables (IV). All variables referring to agricultural family labour and variable farm inputs were instrumented. Due to the difficulty in finding appropriate instruments (the HBS database reports only the expenditure for inputs, without prices), dummy variables for macro-regions were included to account for price variations ${ }^{11}$. In contrast to developing

\footnotetext{
${ }^{9}$ In 2007, the average official exchange rate was 16.5986 MDL/EUR (0.0602 EUR/MDL). In 2013, the two-stage sampling adopted in the HBS resulted in a standard error of \pm 1.35 EUR for individual income estimates, and \pm 1.28 EUR for consumption estimates, at a confidence level of 95\% (NBS, 2017b).

${ }^{10}$ In line with Skoufias (1994), a fixed-effect model was also estimated, and the Hausman test of the random-effects versus fixed-effects specification calculated. The test favoured the latter if both covariance matrices were based on disturbance variance estimates from the efficient estimator, but the difference matrix was not positive definite, putting this result in doubt. The random-effect model was finally retained for several reasons. First, the average number of observations per household is limited (1.3), so that fixed-effects could barely be calculated; second, the R-squared index is significantly higher for the random-effects estimate ( 0.3899 vs. 0.0758$)$; third, the results of the random-effects estimate were in line with those obtained with the generalised method of moments. The follow-up of the analysis was also performed with the shadow wage and incomes calculated from the fixed-effect model, and the results in terms of labour use did not change.

${ }^{11}$ The lists of the variables instrumented and of the instruments are provided in the Tables.
} 
countries in Latin America or Southeast Asia, male and female labour is almost perfectly substitutable in Moldova, while child labour is secondary. Therefore, only the production functions with total family labour are retained in the Results Section. Production functions take the form:

$$
\ln \left(Y_{h, t}\right)=\beta_{0}+\sum_{i} \beta_{i} \ln \left(L_{i}\right)_{h, t}+\sum_{j} \gamma_{j} \ln \left(C_{j}\right)_{h, t}+\sum_{k} \alpha_{k} N_{k, t}+\sum_{l} \delta_{l} \ln \left(G_{l}\right)_{h, t}+\sum_{m} \theta_{m} A_{m_{h, t}}+\sum_{n} \varepsilon_{n} D_{h h, t}+v_{h, t}
$$

301

where $Y_{h, t}$ is the value of the total agricultural production of farming household $h$ in year $t, \beta_{0}$ is a constant term, $\beta_{i}$ 's, $\gamma_{j}$ 's, $\alpha_{k}$ 's, $\delta_{l}$ 's, $\theta_{m}$ 's and $\varepsilon_{n}$ 's are parameters, $L_{i}$ are the hours of $i$ types of labour (either female, male and child separately, or total family labour), $C_{j}$ are the cost of $j$ inputs (including mechanisation services and hired labour), $N_{k}$ are the number of $k$ types of animals, $G_{l}$ are the surfaces (in ares ${ }^{12}$ ) of $l$ types of land ${ }^{13}, A_{m}$ are $m$ household characteristics, $D_{n}$ are location and other variables, and $v$ is an error term for the effect of omitted variables.

Using the coefficients from the production functions, agricultural shadow wages and shadow incomes were calculated. Unlike in previous analyses (Skoufias, 1994; Le, 2009), home labour and self-produced goods were not included in income due to the lack of data. The shadow cost of family labour was obtained by multiplying the shadow wages by the number of hours spent working on the family farm; then, its incidence on total farm costs (including shadow costs) was calculated. The share of internalised inputs was obtained by summing up the costs of self-produced feed and seeds (available in the database) with the shadow cost of family labour ${ }^{14}$. The formulas to calculate shadow wages $\widehat{w}_{i}^{*}{ }_{h, t}(2)$, shadow incomes $\widehat{V}_{h, t}^{*}(3)$, and labour costs $C_{l}$ (4) are, respectively:

$$
\begin{gathered}
\widehat{w}_{i h, t}^{*}=\beta_{i} *\left(\widehat{Y}_{h, t} / L_{i h, t}\right) \\
\hat{V}_{h, t}^{*}=\widehat{Y}_{h, t}-\sum_{i} \widehat{w}_{i h, t}^{*} W_{i_{h, t}}-\sum_{j} C_{j, t}+\sum_{p} I_{p_{h, t}} \\
C_{l}=\sum_{i} \widehat{w}_{h, t}^{*} L_{i h, t}
\end{gathered}
$$

where, for each household $h$ in year $t, \hat{Y}$ is the fitted value of farm output, $W_{i}$ is the labour supplied (both on-farm and off-farm) by each type $i$ of family members (males, females and children), and $I_{p}$ are off-farm incomes, including eventual incomes from renting land, and from providing mechanisation services. The incidence of labour (5), and of internalised inputs (6) are, respectively:

$$
\begin{gathered}
\pi_{l h, t}=C_{l_{h, t}} /\left(C_{l_{h, t}}+\sum_{j} C_{j_{h, t}}\right) \\
\pi_{i_{h, t}=}\left(C_{l_{h, t}}+C_{f_{h, t}}+C_{s_{h, t}}\right) /\left(C_{l_{h, t}}+\sum_{j \neq f, s} C_{j_{h, t}}\right)
\end{gathered}
$$

where $C$ indicates a cost, and $s$ and $f$ (here, as well as in the formulas below) refer to self-produced seeds (and seedlings) and feed, respectively.

Labour supply functions were estimated using two-stage least squares regressions with IV, considering all households with non-zero farm labour (as in Skoufias, 1994) ${ }^{15}$. Then, they were estimated for remittance-recipients and for non-recipient households separately, thus obtaining the elasticity of the labour supply with respect to shadow wages and incomes for both household

\footnotetext{
${ }^{12}$ Due to the small farm sizes, hectares were converted into ares ( 1 are $=0.01$ hectares) to avoid too small coefficients.

${ }^{13}$ Either "small shares", generally used for self-consumption crops, and "big shares", used for orchards or for the extensive cultivation of cereals.

14 The shadow agricultural wage, the shadow income, and the shares of family labour and internalized inputs were calculated from each of the four production functions. The results with total family labour are retained in the Results Section, while those with male, female and child labour separately are presented within the Supplementary material.

${ }^{15}$ Labour supply functions were estimated also for males and females separately (as in Le, 2009); estimates are presented within the Supplementary material.
} 
types. The labour supply functions for total family labour (7), male labour (8), and female labour

(9) take the following forms, respectively:

$$
\begin{gathered}
\ln \left(W_{t o t h, t}\right)=\rho_{0}+\rho_{1} \ln \left(\widehat{w}_{t o t}^{*}, t\right)+\rho_{3} \ln \left(\widehat{V}_{h, t}^{*}\right)+\sum_{m} \theta_{m} B_{m h, t}+\sum_{n} \varepsilon_{n} H_{h h, t}+\eta_{h, t} \\
\ln \left(W_{M h, t}\right)=\rho_{0}^{M}+\rho_{1}^{M} \ln \left(\widehat{w}_{M h, t}^{*}\right)+\rho_{2}^{M} \ln \left(\widehat{w}_{F h, t}^{*}\right)+\rho_{3}^{M} \ln \left(\widehat{V}_{h, t}^{*}\right)+\sum_{m} \theta_{m}^{M} B_{m, t}^{s}+\sum_{n} \varepsilon_{n}^{M} H_{h, t}^{s}+\eta_{h, t} \\
\ln \left(W_{F h, t}\right)=\rho_{0}^{F}+\rho_{1}^{F} \ln \left(\widehat{w}_{F h, t}^{*}\right)+\rho_{2}^{F} \ln \left(\widehat{w}_{M h, t}^{*}\right)+\rho_{3}^{F} \ln \left(\widehat{V}_{h, t}^{*}\right)+\sum_{m} \theta_{m}^{F} B_{m h, t}^{s}+\sum_{n} \varepsilon_{n}^{F} H_{h, t}^{s}+\eta_{h, t}
\end{gathered}
$$

where, for each household $h$ in year $t, W_{\text {tot }}$ and $\widehat{w}_{\text {tot }}^{*}$ indicate, respectively, the labour supply and the shadow wage calculated for all family members, $W_{M}$ and $\widehat{w}_{M}^{*}$ indicate those for male members, and $W_{F}$ and $\widehat{w}_{F}^{*}$ those for female members. $B$ is a vector of household characteristics (different in every equation), $D$ is a vector of location and other variables, $\eta$ is an error term for the effect of omitted variables, and $\rho_{s}$ 's are the parameters to be estimated.

Before testing whether recipient and non-recipient households adopt significantly different production strategies, the two groups were matched using propensity score matching. The propensity score was calculated with a logit regression where the dependent variable was a dummy turning one for remittance recipients, zero otherwise. T-tests of difference of means between remittance recipients and their matched non-recipient peers were implemented for the shares of labour costs and of internalised inputs. A bootstrapped value of the differences was also calculated to test whether it was significantly different from zero.

Nine more production indicators were calculated, and the difference between recipient and non-recipient household tested after propensity score matching; for this analysis, input and output variables were expressed in thousand MDL, family labour in hours, and land in ares:

1. the intensity of purchased inputs on farmed land: $\left(\sum_{j \neq\{f, s\}} C_{j_{h, t}}\right) /\left(\sum_{l} G_{l h, t}\right)$;

2. the intensity of family labour on farmed land: $\left(\sum_{i} L_{i_{h, t}}\right) /\left(\sum_{l} G_{l h, t}\right)$;

3. the ratio of family labour to purchased inputs: $\left(\sum_{i} L_{i h, t}\right) /\left(\sum_{j \neq\{f, s\}} C_{j_{h, t}}\right)$;

4. the ratio of purchased inputs to farm output: $\left(\sum_{j \neq\{f, s\}} C_{j, t}\right) / Y_{h, t}$;

5. the productivity of family labour (farm output unit per unit of family labour): $Y_{h, t} /\left(\sum_{i} L_{i}, t\right)$;

6. the productivity of land (unit of farm output per unit of land farmed): $Y_{h, t} /\left(\sum_{l} G_{l, t}\right)$;

7. the productivity of purchased inputs (unit of farm output per input unit): $Y_{h, t} /\left(\sum_{j \neq\{f, s\}} C_{j_{h, t}}\right)$;

8. the share of animal production in total farm output: $Y_{h, t}^{A} / Y_{h, t}$;

9. the incidence of farm sales (i.e., of monetary farm income) on total output (in kind and in money): $Y_{h, t}^{M} / Y_{h, t}$.

To evaluate whether remittance recipients are more likely to invest in agriculture than nonrecipient households, both qualitative insights from the 2015-smallholder-survey, and econometric analyses were used. First, examples of investments, not necessarily of remittances (e.g. rototillers, greenhouses, walnut orchards, etc.), were identified through the 2015-smallholder-survey, and are provided in the Results Section. In addition to providing information on actual investments, respondent households were asked how they would spend non-repayable sums of 50,000 EUR and 1,000 EUR, respectively. Three investment options that could be detected from the HBS database were selected for further analysis: dairy cattle, agricultural machinery, and arable land (either purchased or rented, since land rental represents a very common instrument for land consolidation, Möllers et al., 2016). Although the literature on remittance investment patterns reveals that receiving households rarely opt for traditional agriculture as a livelihood strategy, these specific investments were chosen to test three findings of the 2015-smallholder-survey. First, small- 
scale milk and cheese production emerged as a viable strategy for providing a constant side income to rural dwellers. Second, apart from traditional farming, agricultural machinery was used either to provide mechanisation services to other smallholders, thus ensuring a discreet income, or to reduce the drudgery of part-time farming (e.g., rototillers). Finally, respondents highlighted the importance of land ownership for achieving self-fulfilment, and some examples of land purchase for performing low-input agriculture were observed.

Only panel households were included in the study of farm investments. An investment (disinvestment) was registered if the variables indicating the asset showed a positive (negative) difference across years. For dairy cattle, the number of heads owned (2008-2013) was considered. For farm machinery, when one of the dummies indicating ownership of tractors, plugs, trailers, combines, or seeders turned from zero to one, an investment was registered, otherwise a disinvestment. For land, if the surface available to a household grew, an investment was registered, otherwise a disinvestment. Categorical variables (investment, no change, and disinvestment) were, thus, created.

The relationship between remittances and farm investments was assessed by means of multinomial logistic regressions of the abovementioned categorical variables on income variables, household characteristics (head age and sex, and family size), and location dummies (for urban areas, and regions). Three income typologies were considered: (1) remittances; (2) earned incomes (salaries and self-employment income); and (3) non-earned incomes (pensions and other welfare payments). For each of the three investments, four models were estimated. In the first model, income variables corresponded to the amount (in thousand MDL) in the current year. In the second one, variables for the amount in the previous year were also included. In the third model, incomes were represented, instead, by dummies for the availability of each type of income in the current year. In the fourth one, dummies for their availability in the previous year were also included ${ }^{16}$. Only the results of the estimate of the second model (with the current and lagged amount of the three income typologies as independent variables) are displayed in the Results Section $^{17}$.

Finally, t-tests were implemented to assess whether the shares of households making one of the three investments differed significantly between remittance recipients and non-recipients. First, the two groups were matched by means of propensity score matching. Bootstrapped values of the differences were also calculated to test whether they were significantly different from zero.

\section{4. $\quad$ Results}

Throughout the entire period 2007-2013, 80\% of the households included in the HBS database owned some land. The average property was 1.49 hectares but, due to leases (mostly to corporate farms, as reported by Möllers et al., 2016), only 0.74 hectares were available on average. The households farming some land were $78 \%$, the average size being 0.30 hectares. Since rural households are overrepresented in the database, more reliable estimates can be obtained for 2013 using sample weights: $72 \%$ of the households owned land (1.32 hectares on average), the same percentage had access to some of it (although only to 0.64 hectares), and $69 \%$ were farming some $(0.29$

\footnotetext{
${ }^{16}$ Since the HBS panel rotates, cumulated incomes along many years could not be calculated. The Variance Inflation Factor was used to check for multicollinearity between current and lagged values, but no multicollinearity was observed.

${ }^{17}$ The results of the estimates of the other models are provided within the Supplementary material.
} 
hectares). Among farming households, the average yearly farm output (including in kind) at constant 2007 prices was 416 EUR over the entire period, and 348 EUR in 2013 (using weights). By comparison, family income accounted for 1,821 EUR and 1,862 EUR, respectively.

In 2013, farm income was the most widespread means of income (70\% of the households), followed by pensions and other welfare payments $(60 \%)$, waged income $(49 \%)$, remittances (23\%), and earnings from off-farm businesses (less than $1 \%$ ). On average, remittances represented the highest sum after waged incomes (460 EUR $v s .858$ EUR), being slightly above welfare payments (409 EUR), more than twice farm revenues (187 EUR), and almost three times the earnings from off-farm businesses (142 EUR). Property income was negligible (4 EUR). For most households, land ownership provided a simple supplement to wages or welfare: those earning over half of their income from farming were only $6 \%$; on average, farming accounted for $13 \%$ of the income (18\% among farming households).

Table 1. Differences between recipient and non-recipient households, and among recipients.

\begin{tabular}{|c|c|c|c|c|c|c|c|c|}
\hline \multirow[t]{2}{*}{ Explanatory variables } & \multicolumn{2}{|c|}{$\begin{array}{c}\begin{array}{c}\text { Logit for remittances } \\
\text { (dummy) }\end{array} \\
\end{array}$} & \multicolumn{2}{|c|}{$\begin{array}{l}\text { Quantile regression } \\
\text { (median) }\end{array}$} & \multicolumn{2}{|c|}{$\begin{array}{l}\text { Quantile regression } \\
\left(75^{\text {th }}\right)\end{array}$} & \multicolumn{2}{|c|}{$\begin{array}{l}\text { Quantile regres- } \\
\text { sion }\left(90^{\text {th }}\right)\end{array}$} \\
\hline & Odd ratios & Std. err. & Coeff. & Std. err. & Coeff. & Std. err. & Coeff. & Std. err. \\
\hline Household size & 1.253 & 0.016 & 2.684 & 0.167 & 5.005 & 0.326 & 7.185 & 0.682 \\
\hline Household head age & 1.008 & 0.007 & -0.430 & 0.091 & -0.571 & 0.178 & -1.100 & 0.372 \\
\hline Household head age (squared) & 1.000 & 0.000 & 0.003 & 0.001 & 0.003 & 0.002 & 0.006 & 0.004 \\
\hline Male household head (dummy) & 0.540 & 0.017 & -1.349 & 0.441 & -1.547 & 0.862 & -0.571 & 1.806 \\
\hline Urban location (dummy) & 1.279 & 0.059 & 0.729 & 0.672 & -0.969 & 1.312 & -5.249 & 2.749 \\
\hline North (dummy) & 0.855 & 0.029 & 3.088 & 0.509 & 2.875 & 0.994 & 1.786 & 2.084 \\
\hline South (dummy) & 1.448 & 0.053 & -1.472 & 0.511 & -3.846 & 0.998 & -8.579 & 2.092 \\
\hline Chișinău (dummy) & 0.938 & 0.095 & 0.295 & 1.577 & -0.194 & 3.079 & -2.897 & 6.451 \\
\hline Earned income $\left(1,000 \mathrm{MDL}^{1}\right)$ & 0.958 & 0.002 & -0.084 & 0.016 & -0.092 & 0.032 & -0.140 & 0.067 \\
\hline Non-earned income $\left(1,000 \mathrm{MDL}^{1}\right)$ & 0.954 & 0.003 & -0.214 & 0.037 & -0.323 & 0.073 & -0.505 & 0.153 \\
\hline Farm income $\left(1,000 \mathrm{MDL}^{1}\right)$ & 0.966 & 0.003 & -0.010 & 0.036 & -0.075 & 0.070 & -0.361 & 0.146 \\
\hline Land farmed (ares) & 1.008 & 0.001 & 0.003 & 0.011 & -0.026 & 0.022 & 0.006 & 0.045 \\
\hline Low education (dummy) & 0.636 & 0.022 & -2.937 & 0.525 & -4.855 & 1.025 & -8.856 & 2.148 \\
\hline High education (dummy) & 1.012 & 0.063 & 2.625 & 0.935 & 6.647 & 1.826 & 14.531 & 3.827 \\
\hline Constant term & 1.191 & 0.202 & 25.469 & 2.256 & 41.444 & 4.405 & 79.830 & 9.230 \\
\hline Number of observations & \multicolumn{2}{|c|}{30,119} & \multicolumn{2}{|c|}{7,871} & \multicolumn{2}{|c|}{7,871} & \multicolumn{2}{|c|}{7,871} \\
\hline
\end{tabular}

The 2015-smallholder-survey showed that, due to the important role of homemade food and agricultural activities for self-reward and social appraisal, many smallholders choose to farm even if it results in financial loss (Piras, 2016). Rather than selling their land, or leaving it fallow, they use their waged income and remittances to cover farm costs. Thirty-five respondents (30\%) had received remittances in the last 12 months, although the frequency was not regular. Based on HBS data for 2013, farming households receiving waged income or remittances were $41 \%$ and $25 \%$, respectively. On average, these represented the largest types of earnings but, unlike for the overall population, among farming households waged income was only slightly above remittances (558 EUR vs. 449 EUR). Furthermore, due to a strongly right-skewed distribution, the average amount of waged income for farming households with off-farm workers was lower than the average remittances for recipient farming households (1,358 EUR vs. 1,551 EUR).

Table 1 shows the results of the logit and quartile regressions identifying the differences between remittance recipients (coded one) and other households (coded zero), and among the former. Recipient households are larger, are more often female-led (probably due to the absence of the husband), more often urban-based or from the south (more rarely from the north or from Chișinău), earn lower "internal" incomes (including from farming, despite using a larger area of land), and are less likely to be poorly educated. Furthermore, younger households, as well as those from rural areas, from the north, and with a higher education tend to receive more remittances. These findings suggest a need to implement propensity score matching. 


\subsection{Remittances and production practices}

441 Table 2 presents two different estimates of the agricultural production functions for the house442 holds using non-zero family labour ${ }^{18}$. Regardless of the estimation method, the direction of the 443 coefficients does not change, meaning that the results are robust. Farm production is positively 444 correlated with family labour, expenditure on seeds, mechanisation services and other inputs, an445 imals (particularly cows) and male household heads. In contrast, hiring labour, larger land areas 446 (both "small shares" and "big shares"), and older ages of the family head have a negative impact. 447 Even the respondents to the 2015-smallholder-survey indicated the low productivity of hired ag448 ricultural workers (Piras, 2016).

450 Table 2. Estimates of the Cobb-Douglas production functions.

\begin{tabular}{|c|c|c|c|c|}
\hline \multirow{2}{*}{ Farm output $\left(1,000 \mathrm{MDL}^{1}\right)(\log )$} & \multicolumn{2}{|c|}{ Random-effects IV regression (Model 1) } & \multicolumn{2}{|c|}{ GMM IV regression (Model 2) } \\
\hline & Coeff. & Std. err. & Coeff. & Std. err. \\
\hline Household labour (hours) $(\log )^{1}$ & 0.2550 & 0.0195 & 0.2686 & 0.0264 \\
\hline Hired labour costs $\left(1,000 \mathrm{MDL}^{2}\right)(\log )^{1}$ & -2.4967 & 0.3800 & -3.9053 & 0.6018 \\
\hline Seed costs $\left(1,000 \mathrm{MDL}^{2}\right)(\log )^{1}$ & 1.2333 & 0.1182 & 1.2566 & 0.1455 \\
\hline Feed costs $\left(1,000 \mathrm{MDL}^{2}\right)(\log )^{1}$ & -0.1683 & 0.1602 & -0.2165 & 0.1856 \\
\hline Other costs $\left(1,000 \mathrm{MDL}^{2}\right)(\log )^{1}$ & 1.1224 & 0.1103 & 1.2104 & 0.1295 \\
\hline Mechanisation services costs $\left(1,000 \mathrm{MDL}^{2}\right)(\log )^{1}$ & 0.7051 & 0.1851 & 0.5300 & 0.2129 \\
\hline Number of cows & 0.1579 & 0.0226 & 0.1579 & 0.0275 \\
\hline Number of sheep & 0.0118 & 0.0020 & 0.0107 & 0.0028 \\
\hline Number of goats & 0.0130 & 0.0060 & 0.0227 & 0.0179 \\
\hline Number of pigs & 0.0099 & 0.0108 & 0.0713 & 0.0227 \\
\hline Number of poultry & 0.0003 & 0.0005 & 0.0004 & 0.0007 \\
\hline Number of other animals & 0.0092 & 0.0013 & 0.0106 & 0.0025 \\
\hline Size of the "small share" (ares) (log) & -0.0371 & 0.0205 & -0.0353 & 0.0249 \\
\hline Size of the "big share" (ares) (log) & -0.2874 & 0.0716 & -0.1603 & 0.0879 \\
\hline Land quality (\%) & -0.0031 & 0.0009 & -0.0026 & 0.0011 \\
\hline Household head age & -0.0040 & 0.0026 & -0.0054 & 0.0028 \\
\hline Household head age squared & 0.0000 & 0.0000 & 0.0000 & 0.0000 \\
\hline Male household head (dummy) & 0.0880 & 0.0129 & 0.0992 & 0.0143 \\
\hline Education low (dummy) & 0.0166 & 0.0133 & 0.0097 & 0.0146 \\
\hline Education high (dummy) & 0.0195 & 0.0274 & 0.0491 & 0.0402 \\
\hline R-squared & \multicolumn{2}{|c|}{0.3899} & \multicolumn{2}{|c|}{0.2926} \\
\hline Number of observations & \multicolumn{2}{|c|}{16,426} & \multicolumn{2}{|c|}{16,426} \\
\hline
\end{tabular}

Notes: ${ }^{1}$ Endogenous variables. ${ }^{2} 1,000$ MDL correspond to 60 EUR.

Instruments: number of family members working on the farm, number of adult family members (aged 18 to 64), number of children (aged 4 to 17), number of elderly people (aged over 64), dummy for ownership of a tractor, dummy for urban locations, and regional dummies to account for price variations. Dummies for the year and the month of the interview and for inputs with zero value, and intercepts included in the regressions but not shown in the table. Constant of one added to all inputs before taking the logarithm. Source: Authors' elaboration on data from the Moldovan HBS

Table 3 gives the estimates of the labour supply functions. The elasticity of the labour supply with respect to the shadow agricultural wage is clearly positive ${ }^{19}$, while its elasticity with respect to the shadow income is negative, as expected. The coefficients maintain the same signs when the functions are estimated separately for remittance recipients and non-recipients. However, the elasticities with respect to the shadow wages (either negative or positive) and incomes (negative) are higher among recipients, meaning that the latter are more reactive to changes in these variables. Furthermore, the amount of labour supplied by Moldovan families is positively associated with the number of adult members, being married — as also detected by Skoufias (1994) using Indian data - and with higher ages of the family head (although it decreases for very old ages). In comparison, it is negatively associated with high education levels, probably due to the higher productivity of labour in this case.

\footnotetext{
18 The test for endogeneity indicates that the variables instrumented are, indeed, endogenous.

${ }^{19}$ When the labour supply functions for male and female members are estimated separately, the elasticity with respect to their own shadow wage is negative, suggesting that the labour supply curve is S-shaped for wages close to the subsistence level (Dessing, 2002). Furthermore, the opposite signs of the coefficients associated with the wages of family members of different sex provides evidence of a substitution effect between male and female labour. Tables with the results of the estimates are provided in the Supplementary material.
} 

and incomes calculated respectively from Model 1 and Model 2 of Table 2.

\begin{tabular}{|c|c|c|c|c|c|c|}
\hline Shadow wage and income from Model 1 & \multicolumn{2}{|c|}{ All households } & \multicolumn{2}{|c|}{ Remittance recipients } & \multicolumn{2}{|c|}{ Non-recipient families } \\
\hline Household labour supply (hours) (log) & Coeff. & Std. err. & Coeff. & Std. err. & Coeff. & Std. err. \\
\hline Household shadow wage $\left(1,000 \mathrm{MDL}^{2}\right)(\log )^{1}$ & 189.5492 & 14.2934 & 188.0882 & 26.5480 & 166.8521 & 15.1744 \\
\hline Shadow income $\left(1,000 \mathrm{MDL}^{2}\right)(\log )^{1}$ & -0.2421 & 0.0260 & -0.1579 & 0.0292 & -0.1499 & 0.0485 \\
\hline Household head age & 0.0126 & 0.0052 & 0.0110 & 0.0069 & 0.0121 & 0.0065 \\
\hline Household head age squared & -0.0001 & 0.0000 & -0.0001 & 0.0001 & -0.0001 & 0.0001 \\
\hline Married (dummy) & 0.3199 & 0.0286 & 0.1164 & 0.0431 & 0.3666 & 0.0348 \\
\hline Education low (dummy) & 0.0184 & 0.0250 & 0.0527 & 0.0364 & 0.0009 & 0.0285 \\
\hline Education high (dummy) & -0.1651 & 0.0542 & -0.1561 & 0.0834 & -0.1948 & 0.0614 \\
\hline Number of adults & 0.3543 & 0.0127 & 0.3813 & 0.0169 & 0.3215 & 0.0162 \\
\hline Number of children & 0.0750 & 0.0136 & 0.0575 & 0.0163 & 0.0771 & 0.0172 \\
\hline Number of infants & 0.0319 & 0.0300 & -0.0137 & 0.0370 & 0.0367 & 0.0379 \\
\hline Over-identification (p-value) & \multicolumn{2}{|c|}{0.0294} & \multicolumn{2}{|c|}{0.0000} & \multicolumn{2}{|c|}{0.0000} \\
\hline Number of observations & \multicolumn{2}{|c|}{16,426} & \multicolumn{2}{|c|}{4,748} & \multicolumn{2}{|c|}{11,678} \\
\hline Shadow wage and income from Model 2 & \multicolumn{2}{|c|}{ All households } & \multicolumn{2}{|c|}{ Remittance recipients } & \multicolumn{2}{|c|}{ Non-recipient families } \\
\hline Household labour supply (hours) (log) & Coeff. & Std. err. & Coeff. & Std. err. & Coeff. & Std. err. \\
\hline Household shadow wage $\left(1,000 \mathrm{MDL}^{2}\right)(\log )^{1}$ & 146.6000 & 11.8192 & 179.5616 & 25.5652 & 122.8072 & 11.8895 \\
\hline Shadow income $\left(1,000 \mathrm{MDL}^{2}\right)(\log )^{1}$ & -0.2292 & 0.0280 & -0.1551 & 0.0318 & -0.1396 & 0.0518 \\
\hline Household head age & 0.0137 & 0.0055 & 0.0119 & 0.0075 & 0.0119 & 0.0068 \\
\hline Household head age squared & -0.0001 & 0.0001 & -0.0001 & 0.0001 & -0.0001 & 0.0001 \\
\hline Married (dummy) & 0.3179 & 0.0306 & 0.1062 & 0.0474 & 0.3613 & 0.0366 \\
\hline low (dumm & 0.0225 & 0.0267 & 0.0667 & 0.0402 & 0.0041 & 0.0298 \\
\hline Education high (dummy) & -0.1738 & 0.0582 & -0.1540 & 0.0911 & -0.1983 & 0.0645 \\
\hline Number of adults & 0.3442 & 0.0139 & 0.3726 & 0.0186 & 0.3153 & 0.0172 \\
\hline Number of children & 0.0729 & 0.0146 & 0.0529 & 0.0180 & 0.0753 & 0.0181 \\
\hline Number of infants & 0.0304 & 0.0321 & -0.0121 & 0.0404 & 0.0277 & 0.0395 \\
\hline Over-identification (p-value) & \multicolumn{2}{|c|}{0.0382} & \multicolumn{2}{|c|}{0.0000} & \multicolumn{2}{|c|}{0.0001} \\
\hline Number of observations & \multicolumn{2}{|c|}{16,426} & \multicolumn{2}{|c|}{4,748} & \\
\hline
\end{tabular}

Notes: ${ }^{1}$ Endogenous variables. ${ }^{2} 1,000$ MDL correspond to 60 EUR.

Instruments: exogenous income of the household (1,000 MDL - 60 EUR) (log), area of land farmed (ares) (log), number of family members working on the farm (aged 18 to 64), and dummy for urban locations. Dummies for the year and the month of the interview, for the region and for zero or negative shadow incomes, and intercepts included in the regressions but not shown in the table. Constant of one added to all inputs before taking the logarithms.

466

The results of the tests of difference in the mean incidence of family labour and of internalised input costs between recipient and non-recipient households are shown in Table 4. The difference in the shadow wages was also tested, but it was found to be non-significant. The incidence of family labour and of internalised inputs on total farm costs differs significantly regardless of the estimation method. Family labour accounts for 50-52\% of farm costs among recipients, compared to 53-55\% among non-recipients. Internalised inputs account for 58-59\% and 62-63\%, respectively. These results suggest that recipients tend to substitute family labour and self-produced inputs with mechanisation services provided by contractors (as also observed during the 2015-smallholder-survey), and with purchased inputs.

Table 4. Incidence of family labour (calculated from Model 1 and Model 2 of Table 2) and of internalised inputs on total farm expenditures among recipient and non-recipient households.

\begin{tabular}{|c|c|c|c|c|c|c|c|}
\hline Variable & & Recipients & Others & Diff. & Std. err. & Bootstr. diff. & Std. err. \\
\hline \multirow{2}{*}{$\begin{array}{l}\text { Share of labour } \\
\text { costs (from Model 1) }\end{array}$} & Unmatched & 0.5019 & 0.5272 & -0.0253 & 0.0026 & \multirow[b]{2}{*}{-0.0409} & \multirow{2}{*}{0.0026} \\
\hline & Matched & 0.5011 & 0.5326 & -0.0316 & 0.0044 & & \\
\hline \multirow{2}{*}{$\begin{array}{l}\text { Share of internalised } \\
\text { inputs (from Model 1) }\end{array}$} & Unmatched & 0.5782 & 0.6188 & -0.0406 & 0.0028 & \multirow{2}{*}{-0.0494} & \multirow{2}{*}{0.0027} \\
\hline & Matched & 0.5779 & 0.6173 & -0.0394 & 0.0047 & & \\
\hline \multirow{2}{*}{$\begin{array}{l}\text { Share of labour } \\
\text { costs (from Model 2) }\end{array}$} & Unmatched & 0.5158 & 0.5435 & -0.0277 & 0.0028 & \multirow{2}{*}{-0.0429} & \multirow{2}{*}{0.0029} \\
\hline & Matched & 0.5151 & 0.5481 & -0.0331 & 0.0046 & & \\
\hline \multirow{2}{*}{$\begin{array}{l}\text { Share of internalised } \\
\text { inputs (from Model 2) }\end{array}$} & Unmatched & 0.5896 & 0.6317 & -0.0421 & 0.0029 & \multirow{2}{*}{-0.0509} & \multirow{2}{*}{0.0030} \\
\hline & Matched & 0.5893 & 0.6297 & -0.0403 & 0.0049 & & \\
\hline
\end{tabular}

Notes: Households matched on the number of adult members, their average age (and its squared value), the gender of the household head, location dummies (urban settlement, north, centre and south; Chișinău omitted), earned income (1,000 MDL - 60 EUR), non-earned income (1,000 MDL - 60 EUR), farm income (1,000 MDL - 60 EUR), available land (ares), and year dummies. Values calculated on 16,324 households (2008-2013) producing a non-zero farm output and using a non-zero amount of family labour for which the propensity score could be estimated (11,677 untreated, 4,647 treated).

Source: Authors' elaboration on data from the Moldovan HBS.

All production indicators assume values that are significantly different between remittance recipient and non-recipient households, as shown in Table 5. On average, recipient households 
spend 523 EUR on purchased inputs, and employ 7,100 hours of family labour per hectare farmed, compared to 489 EUR and 7,830 hours among non-recipients. Hence, remittance recipients show higher labour productivity ( $0.36 v s .0 .33$ EUR per hour), and lower land productivity (1,018 EUR vs. 1,100 EUR per hectare). Due to the lower labour to inputs ratio (15.4 vs. 17.2 hours per EUR spent), the incidence of monetary costs on farm production is higher among them (39\% vs. $32 \%)$, and the productivity of purchase input lower (4.12 vs. 4.36 units per unit spent). Finally, recipients obtain a higher share of their farm output from animal breeding (39\% vs. 37\%), and sell a smaller share of their production $(11 \% \mathrm{vs} .15 \%)^{20}$. The latter figure seems to confirm the qualitative finding of the 2015-smallholder-survey, reported by Piras (2016), that many smallholders who earn a good income off-farm (including remittances from household members) continue to engage in agriculture (eventually part-time) for non-financial reasons. Indeed, this survey showed that working one's land and producing one's own food yields self-fulfilment and social appraisal, especially in the villages. These smallholders are not interested in systematic commercialisation of farm output.

Table 5. Difference in the values of production indexes among recipients and non-recipients.

\begin{tabular}{|c|c|c|c|c|c|c|c|}
\hline Variable & & Recipients & Others & Diff. & Std. err. & Bootstr. diff. & Std. err. \\
\hline \multirow{2}{*}{$\begin{array}{l}\text { Intensity of purchased inputs } \\
\text { on land }\left(1,000 \mathrm{MDL} / \operatorname{are~}^{1}\right)\end{array}$} & Unmatched & 0.0877 & 0.0753 & 0.0124 & 0.0026 & \multirow{2}{*}{0.0101} & \multirow{2}{*}{0.0030} \\
\hline & Matched & 0.0868 & 0.0812 & 0.0056 & 0.0044 & & \\
\hline \multirow{2}{*}{$\begin{array}{l}\text { Intensity of labour } \\
\text { on land (hours/are) }\end{array}$} & Unmatched & 71.3463 & 76.3946 & $\begin{array}{l}-5.0483 \\
\end{array}$ & 1.7752 & \multirow{2}{*}{-5.1070} & \multirow{2}{*}{2.1189} \\
\hline & Matched & 71.0343 & 78.2994 & -7.2651 & 3.0176 & & \\
\hline \multirow{2}{*}{$\begin{array}{l}\text { Labour to input ratio } \\
\text { (hours } / 1,000 \mathrm{MDL}^{1} \text { ) }\end{array}$} & Unmatched & 920.6582 & 1045.7013 & -125.0432 & 14.7387 & \multirow[b]{2}{*}{-134.9787} & \multirow[b]{2}{*}{17.1630} \\
\hline & Matched & 926.1547 & 1038.0795 & -111.9248 & 23.9181 & & \\
\hline \multirow{2}{*}{$\begin{array}{l}\text { Purchased input cost } \\
\text { on farm output }\end{array}$} & Unmatched & 0.3932 & 0.2983 & 0.0949 & 0.0110 & \multirow{2}{*}{0.0495} & \multirow{2}{*}{0.0086} \\
\hline & Matched & 0.3871 & 0.3187 & 0.0684 & 0.0148 & & \\
\hline \multirow{2}{*}{$\begin{array}{l}\text { Labour productivity } \\
\left(1,000 \mathrm{MDL} / \text { hour }^{1}\right)\end{array}$} & Unmatched & 0.0060 & 0.0059 & 0.0000 & 0.0001 & \multirow{2}{*}{0.0008} & \multirow{2}{*}{0.0001} \\
\hline & Matched & 0.0060 & 0.0055 & 0.0005 & 0.0002 & & \\
\hline \multirow{2}{*}{$\begin{array}{l}\text { Land productivity } \\
\left(1,000 \text { MDL/are }{ }^{1}\right)\end{array}$} & Unmatched & 0.1689 & 0.1924 & -0.0234 & 0.0051 & \multirow{2}{*}{-0.0124} & \multirow{2}{*}{0.0044} \\
\hline & Matched & 0.1689 & 0.1826 & -0.0137 & 0.0082 & & \\
\hline \multirow{2}{*}{$\begin{array}{l}\text { Productivity } \\
\text { of purchased inputs }\end{array}$} & Unmatched & 4.0950 & 4.6440 & -0.5489 & 0.0614 & \multirow{2}{*}{-0.1529} & \multirow{2}{*}{0.0778} \\
\hline & Matched & 4.1181 & 4.3632 & -0.2452 & 0.0967 & & \\
\hline \multirow{2}{*}{$\begin{array}{l}\text { Animal production on } \\
\text { total farm production }\end{array}$} & Unmatched & 0.3940 & 0.3761 & 0.0180 & 0.0038 & \multirow{2}{*}{0.0252} & \multirow[b]{2}{*}{0.0043} \\
\hline & Matched & 0.3949 & 0.3722 & 0.0227 & 0.0063 & & \\
\hline \multirow{2}{*}{$\begin{array}{l}\text { Farm sale on total } \\
\text { farm production }\end{array}$} & Unmatched & 0.1123 & 0.1454 & -0.0331 & 0.0033 & \multirow{2}{*}{-0.0233} & \multirow[t]{2}{*}{0.0045} \\
\hline & Matched & 0.1133 & 0.1518 & -0.0385 & 0.0055 & & \\
\hline
\end{tabular}

Notes: ${ }^{1} 1,000$ MDL correspond to 60 EUR. Households matched on the same variables as in Table 4. Values calculated on 18,831 households (2007-2013) producing a non-zero farm output and using non-zero family labour for which the propensity score could be estimated, and the index calculated (18,682 for input intensity, labour intensity and land productivity; 15,257 for labour to inputs ratio and input productivity; 18,723 for farm sales, animal output, input costs on farm production, and labour productivity). Source: Authors' elaboration on data from the Moldovan HBS.

\section{4.2. Remittances and agricultural investments}

500 The 2015-smallholder-survey confirmed smallholders' difficulties in obtaining a bank loan, and highlighted that interest rates are high (over $20 \%$ in 2015). The only options for those lacking collateral, or a means of transport to cities (where banks are located) are formal loans from villagebased credit agencies, or informal private loans. These are usually small, short-term loans, and are thus used for current expenditures. For example, the credit agency whose accountant was interviewed was supplying one- or two-year loans of 500 EUR (2015) on average, at an interest rate of $31 \%$ (the crisis of the Russian rouble had caused interest rates to raise). Furthermore, the smallholders whose loan requests were approved had to give their land as collateral. Private loans imply no administrative burdens, and low or even no interest, but generate an uncomfortable moral obligation to maintain good relationships with the moneylender. Indeed, the latter is often

${ }^{20}$ Any difference between the figures presented in the paragraph and those shown in Table 5 is due to the use of different units, and to the subsequent conversion of MDL into EUR. Indeed, to avoid obtaining too small coefficients, land variables in the database were converted into ares ( 1 are $=0.01$ hectares), and monetary values into 1,000 MDL, which correspond to 60 EUR. 
510 a large farmer renting the "big share" of the creditor. Smallholders usually ask for such loans at 511 the beginning of the agricultural year, and pay them back after harvesting.

Only 14 respondents (12\%), with farms generally larger than the average (ten of them were above two hectares, five above five hectares), had received a loan in the 12 months before the 2015-smallholder-survey. Seven had received a formal loan averaging 3,364 EUR (2015) and seven an informal one averaging 507 EUR (2015). One respondent with a farm size of 7.2 hectares had obtained 6,460 EUR (2015) within the framework of a development project funded by the Japan International Cooperation Agency, but this was the only such case detected. Although international grants for farm modernisation are becoming increasingly available thanks to the Association Agreement with the EU, no ad hoc program for assisting smallholders is currently in place as the government presumes that, as a first step, smallholders should gather in producers' groups in order to overcome the small size constraint and gain access to investment funds ${ }^{21}$. Unlike loans or grants, remittances are available to many smallholders, and pose a much lower administrative burden.

To assess the propensity of survey respondents to invest in agriculture, they were asked how they would spend a non-repayable sum of 50,000 EUR 22 . A relative majority (31\%) stated that they would invest in housing, $27 \%$ in farming and related activities (including food processing), $12 \%$ would give this sum to a younger relative (a child or a grandchild), $11 \%$ would open a non-farm business, and $18 \%$ mentioned a different option. As for those interested in agriculture, given the low levels of mechanisation, many would purchase farm machinery (tractors or combines); the second largest group would build storage facilities (including cold storage houses); and others would invest in permanent crops, mostly walnuts or vineyards. Some mentioned animal farming (cattle, rabbits, beekeeping), or related activities (slaughterhouses). Only three would purchase more land, while two spoke about rural tourism.

Respondents were also asked how they would spend a non-repayable sum of 1,000 EUR usable only in agriculture, to see if they preferred to cover their current expenditures, or to make a small investment ${ }^{23}$. Thirty-six percent opted for the former option: most of them mentioned seeds, followed by mechanisation services; some named irrigation services, fertilisers, and young animals. Sixty-four percent opted, however, to invest: in seedlings, usually walnut trees $(21 \%)$, small greenhouses (11\%), farm equipment, large part rototillers (10\%), arable land (9\%), vineyards $(6 \%)$, dairy cattle (6\%), and drop irrigation facilities (4\%). Such answers point to a certain interest in the small-scale intensification of farm production.

Finally, respondents were asked whether they had used remittances to cover farm expenditures: out of 35 recipient households, 22 answered positively. The sum received was often enough to make small investments. One respondent used remittances from Ireland to buy ten "big shares" for planting walnut trees: this operation required much time due to the difficulty in convincing other smallholders to sell their land, and in finding contiguous plots. Using money earned in Russia, a young family started a small pig farm, and purchased a large tractor that they were using to provide mechanisation services to fellow farmers. After having received a rototiller from his child working in Italy, an old agronomist began growing strawberries and gooseberries in his large home garden, and was earning a decent income by selling them ${ }^{24}$. With remittances from Spain,

\footnotetext{
${ }^{21}$ Partially based on the interview with the rural development officer of the EU Delegation.

22 This was not a closed-ended question: respondents were allowed to express their ideas, and their answers were then classified according to pre-set categories. The total sums up to over $100 \%$ since respondents were allowed to mention more than one option.

${ }^{23}$ Also in this case, respondents were allowed to express their ideas, then their answers were assigned to a category.

${ }^{24}$ Berries emerged as a profitable production for smallholders, although the lack of irrigation represented a strong constraint.
} 
a household renovated some greenhouses dating back to Soviet times to produce vegetables for sale. After coming back from Russia, another dug a lake where people could fish for a fee, and created a small ethnographic museum by gathering traditional objects. These remittances originated from many countries, primarily Russia and Italy. However, it is not always easy to detect the impact of remittances, as they are often earned by a relative, and enter the budget of the families as donations, including in-kind.

Previous findings point to the relationship between migration and diversification, either onfarm or off-farm. This issue has been extensively researched in the literature. Focusing on Northern China, Démurger et al. (2010) find that the decision to diversify on-farm is driven by the availability of land, while the main determinants of off-farm diversification are a family's wealth (especially for self-employment), higher levels of education, and access to social networks. The answers from Moldovan smallholders confirm that to pursue non-farm self-employment, a sizeable investment is required. Instead, diversification of farm activities could be achieved at a limited cost and, unlike in Northern China, with limited land endowment. This is confirmed by what was observed in Romania, a culturally-similar and geographically proximate country, where $37 \%$ of the farming households (compared to $30 \%$ of corporate farms) engage in farm-related activities, such as food processing (Albiou et al., 2011). Off-farm diversification in Romania consists mainly in taking up waged jobs, to the extent that the largest share of family income is often earned offfarm (Davidova and Thomson, 2013).

Table 6. Relationship between farm investments or disinvestments, and the values (current, and first lag) of different types of income.

\begin{tabular}{|c|c|c|c|c|c|c|c|}
\hline \multirow{2}{*}{$\begin{array}{l}\text { Out- } \\
\text { put }\end{array}$} & \multirow{2}{*}{ Explanatory variables } & \multicolumn{2}{|c|}{ Dairy cattle } & \multicolumn{2}{|c|}{ Farm equipment } & \multicolumn{2}{|c|}{ Farmland } \\
\hline & & R.R.R. & Std. err. & R.R.R. & Std. err. & R.R.R. & Std. err. \\
\hline \multirow{10}{*}{ 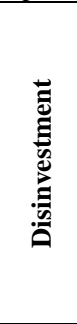 } & Remittances $\left(1,000 \mathrm{MDL}^{1}\right)(\mathrm{t})$ & 1.002 & 0.004 & 0.995 & 0.005 & 0.996 & 0.003 \\
\hline & Non-earned income $\left(1,000 \mathrm{MDL}^{1}\right)(\mathrm{t})$ & 0.993 & 0.012 & 0.986 & 0.018 & 0.979 & 0.009 \\
\hline & Earned income $\left(1,000 \mathrm{MDL}^{1}\right)(\mathrm{t})$ & 0.991 & 0.006 & 0.983 & 0.011 & 0.989 & 0.005 \\
\hline & Remittances $\left(1,000 \mathrm{MDL}^{1}\right)(\mathrm{t}-1)$ & 0.997 & 0.005 & 1.006 & 0.003 & 1.000 & 0.004 \\
\hline & Non-earned income $(1,000 \mathrm{MDL})(\mathrm{t}-1)$ & 1.008 & 0.012 & 0.992 & 0.017 & 1.006 & 0.007 \\
\hline & Earned income $\left(1,000 \mathrm{MDL}^{1}\right)(\mathrm{t}-1)$ & 1.001 & 0.005 & 0.994 & 0.010 & 0.999 & 0.005 \\
\hline & Mean adult age & 1.082 & 0.030 & 1.122 & 0.050 & 0.998 & 0.017 \\
\hline & Mean adult age (squared) & 0.999 & 0.000 & 0.999 & 0.000 & 1.000 & 0.000 \\
\hline & Male household head (dummy) & 1.389 & 0.188 & 1.720 & 0.376 & 1.025 & 0.088 \\
\hline & Household size & 1.368 & 0.064 & 1.243 & 0.099 & 1.060 & 0.038 \\
\hline \multicolumn{8}{|c|}{ No variation (base outcome) } \\
\hline \multirow{10}{*}{ 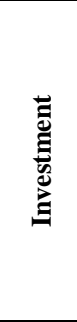 } & Remittances $\left(1,000\right.$ MDL $\left.^{1}\right)(\mathrm{t})$ & 1.003 & 0.004 & 1.002 & 0.006 & 1.003 & 0.003 \\
\hline & Non-earned income $(1,000 \mathrm{MDL})(\mathrm{t})$ & 0.987 & 0.015 & 0.971 & 0.022 & 1.025 & 0.006 \\
\hline & Earned income $\left(1,000 \mathrm{MDL}^{1}\right)(\mathrm{t})$ & 0.988 & 0.006 & 1.002 & 0.007 & 1.008 & 0.003 \\
\hline & Remittances $\left(1,000 \mathrm{MDL}^{1}\right)(\mathrm{t}-1)$ & 0.981 & 0.006 & 0.982 & 0.011 & 0.995 & 0.003 \\
\hline & Non-earned income $\left(1,000 \mathrm{MDL}^{1}\right)(\mathrm{t}-1)$ & 0.995 & 0.014 & 0.984 & 0.026 & 0.972 & 0.009 \\
\hline & Earned income $\left(1,000 \mathrm{MDL}^{1}\right)(\mathrm{t}-1)$ & 0.987 & 0.006 & 0.982 & 0.007 & 0.992 & 0.004 \\
\hline & Mean adult age & 1.102 & 0.036 & 1.172 & 0.060 & 1.013 & 0.018 \\
\hline & Mean adult age (squared) & 0.999 & 0.000 & 0.998 & 0.001 & 1.000 & 0.000 \\
\hline & Male household head (dummy) & 1.676 & 0.270 & 2.083 & 0.492 & 0.966 & 0.080 \\
\hline & Household size & 1.427 & 0.065 & 1.416 & 0.077 & 1.113 & 0.035 \\
\hline \multicolumn{2}{|c|}{ Number of observations } & \multicolumn{2}{|c|}{6,522} & \multicolumn{2}{|c|}{8,190} & \multicolumn{2}{|c|}{8,190} \\
\hline \multicolumn{8}{|c|}{$\begin{array}{l}\text { Notes: }{ }^{1} 1,000 \text { MDL correspond to } 60 \text { EUR. Dummies for urban location, north, south and Chișinău, and intercepts included in the } \\
\text { regressions but not shown in the table. R.R.R.: Relative-Risk Ratio, i.e. risk of the outcome, relative to the base outcome, for a one- } \\
\text { unit change of the independent variable. Significant coefficients marked in bold. } \\
\text { Source: Authors' elaboration on data from the Moldovan HBS. }\end{array}$} \\
\hline
\end{tabular}

Table 6 contains the results of the multinomial logistic regressions for agricultural investments, or disinvestments. In most cases, the relative-risk ratios are not significant, meaning that no correlation could be detected between the amount of remittances, earned incomes and/or nonearned incomes received in the current or previous year, and a family's propensity to purchase or sell farm assets. In most cases, when the ratios are significant, they are below 1, meaning that the probability of either selling or purchasing farm assets is lower than the probability of staying in the same situation if the smallholder has access to higher off-farm sums. This seems in line with the finding of the 2015-smallholder-survey, that farming households whose members have a well- 
paid non-agricultural job prefer to pursue off-farm-centred livelihoods, while keeping the farm for lifestyle or reputational reasons. A partial exception is investments in land: the relative-risk ratio of selling decreases by $2.1 \%$ for each additional 60 EUR (1,000 MDL) of non-earned income, and by $1.1 \%$ for earned income, while the relative-risk ratio of purchasing increases by $2.5 \%$ and $0.8 \%$, respectively. The opposite is true for dairy cattle (the relative-risk ratio of purchasing always decreases for increasing incomes). During the 2015-smallholder-survey, dairy cattle emerged as a successful investment for families wanting to earn a limited income by selling cheese and sour cream. Finally, larger households, those headed by a male, and those with an older head (although not too old) appear more dynamic in terms of both sales and purchases, as the relative-risk ratios associated with these variables are above 1 for all outcomes.

Table 7 shows that the share of recipient households investing in farming is not significantly different from that of non-recipient households. Around $4 \%$ of the families of either group purchased dairy cattle, $9 \%$ increased their land endowment, and less than $2 \%$ of remittance recipients purchased farm machinery, compared to almost $3 \%$ among non-recipient households.

Table 7. Incidence of investors among recipient and non-recipient households.

\begin{tabular}{|c|c|c|c|c|c|c|c|}
\hline Variable & & Recipients & Others & Difference & Std. err. & Bootstr. diff. & Std. err. \\
\hline \multirow{2}{*}{ Purchasers of dairy cattle } & Unmatched & 0.0406 & 0.0409 & -0.0003 & 0.0056 & \multirow{2}{*}{-0.0027} & \multirow{2}{*}{0.0081} \\
\hline & Matched & 0.0422 & 0.0404 & 0.0018 & 0.0092 & & \\
\hline \multirow{2}{*}{ Purchasers of farm equipment } & Unmatched & 0.0165 & 0.0183 & -0.0017 & 0.0033 & \multirow{2}{*}{-0.0018} & \\
\hline & Matched & 0.0166 & 0.0270 & -0.0104 & 0.0058 & & 0.0040 \\
\hline \multirow{2}{*}{ Purchasers of farmland } & Unmatched & 0.0942 & 0.0959 & -0.0017 & 0.0074 & \multirow{2}{*}{-0.0029} & \\
\hline & Matched & 0.0932 & 0.0890 & 0.0043 & 0.0116 & & 0.0108 \\
\hline
\end{tabular}

Notes: Households matched on the number of adult members, their average age (and its squared value), the gender of the household head, location dummies (urban settlement, north, centre and south; Chișinău omitted), earned income (1,000 MDL - 60 EUR), nonearned income (1,000 MDL - 60 EUR), farm income (1,000 MDL - 60 EUR), land owned the previous year (ares), and year dummies. Source: Authors' elaboration on data from the Moldovan HBS.

\section{$599 \quad$ 5. Conclusions}

600 Using data from the Moldovan HBS for the period 2007-2013, and the findings of an original 601 mixed-methods survey of Moldovan smallholders carried out in 2015, this paper assessed the 602 impact of remittances on the production practices and investments of farming households in Mol603 dova.

The households whose members receive remittances are usually larger, younger, and better educated, thus representing the most dynamic part of the society. The HBS estimates of the labour supply functions showed that remittance recipients are also more likely to respond to economic incentives, such as higher agricultural shadow wages. Furthermore, it emerged that they tend to replace family labour and self-produced inputs (seeds, seedlings, and animal feed) with services provided by contractors and purchased inputs, respectively. Both results (non-negative shadow wages and the substitution of family labour with purchased inputs and services) indicate that hidden unemployment does not play an important role, and that the time constraints of migrant households are binding. Remittance-receiving households display higher labour productivity at the expense of lower land and input productivity; however, production or commercialisation levels do not necessarily increase. These findings, together with what was observed during the 2015-smallholder-survey, suggest that remittance recipients engage in agriculture mostly to achieve lifestyle and social rewards, and are thus willing to reduce their drudgery.

As for investments, three options were considered: dairy cattle, machinery, and farmland. The analysis of the HBS data showed that farming households that receive a larger amount of 
619 remittances are not significantly more likely to either sell or purchase farm assets ${ }^{25}$. On the one 620 hand, this may confirm the previous observation that they engage in farming for non-financial reasons, and as such do not need to increase the economic size of their farm. On the other hand, this may suggest that they are caught in a "poverty trap", where the money earned abroad is not enough to invest in farm growth, but they cannot quit farming because it provides a necessary supplement to ensure family survival. This hypothesis needs to be further researched.

The results of the 2015-smallholder-survey show a partially different situation. Indeed, most of the small improvements observed among respondents were possible thanks to the availability of remittances. A widespread interest for small investments aimed at intensifying farm production to ensure a constant income supplement also emerged among respondent families. While the econometric analysis confirmed the finding of Bolganschi (2011) that few migrant households invest in agriculture, qualitative insights suggest that most farming households who invest in agriculture are remittance recipients, as few alternative financing opportunities exist for them.

Agricultural Census data show that most Moldovan land recipients maintain the property of their plots, and engage in agriculture at least as a side activity. While, on the one hand, this may limit access to land for potential investors, obstructing a more efficient use of it, on the other hand, this means that many households have a base from which to build a middle-sized commercial farm. The results of this analysis suggest that, due to their widespread availability, remittances could provide an effective starting point for policy makers. Co-funding of remittance-financed projects could be one way to stimulate investments, and improve the efficiency of grants (VargasLundius et al., 2002). The 2015-smallholder-survey indicated a preference for small intensification projects (greenhouses, recovery of orchards, purchase of rototillers, etc.), rather than farm growth. Giving priority to such projects in funding programs would allow the land to flow into middle-sized family businesses instead of large corporate farms, thus achieving a farm structure more similar to market economies (Lerman and Sutton, 2008), and a fairer distribution of rural incomes $^{26}$.

However, investments need a supportive business environment. Therefore, policy makers should pay attention to removing any obstacles which prevent recipient farming households from investing in agriculture. One of the main challenges is "systematic corruption", as also recognised by the European Council (2016). Corruption not only obstructs the implementation of the Association Agreement with the EU, but also feeds parasitic rent-seekers while choking small investors, and thus needs to be addressed. Furthermore, "systemic risks like draught and frosts", which hit smallholders particularly hard, endangering their investments, require the design of a viable system of farm insurance, which is currently missing (World Bank, 2015: 5). Finally, the unreliability of markets (Moroz et al., 2015) could be reduced, e.g., by negotiating preferential access to the EU market for agro-food products made by smallholders.

One limit of this study consists in the fact that the HBS was conceived for a different purpose and, as such, some relevant variables are missing. Furthermore, the role of informal channels and of personal relationships in the circulation of remittances may prevent quantitative surveys from effectively detecting their actual uses. As for the 2015-smallholder-survey, the small sample size could cast doubts on its representativeness. Nevertheless, while rare phenomena were prob-

\footnotetext{
${ }^{25}$ However, the same is true for all households who have access to larger off-farm incomes. These households are slightly more likely to purchase farmland, and slightly less likely to purchase dairy cattle.

${ }^{26}$ Lerman and Sutton (2008: 101) state that, instead, the Moldovan government "biases its policies in favour of large farms". The persistence of this bias may be proved by the lack of ad hoc programs for smallholders, highlighted during the interview with the rural development officer of the EU Delegation.
} 
ably missed, the overall dynamics detected remain reliable, and the narration of individual experiences holds an important added value. With a view to maximising the impact of the EU rural development programs targeting Moldova, ad hoc qualitative surveys are thus needed to look at the role of remittances in agricultural change and to identify the obstacles preventing the investment of these sums.

\section{Acknowledgments}

This research is partly based on the PhD dissertation of Simone Piras, elaborated under the supervision of Matteo Vittuari. The database of the Moldovan Household Budget Survey could be accessed thanks to the collaboration of Simone Piras, Judith Möllers, and Thomas Herzfeld to the World Bank's Moldova Poverty Assessment 2016. Special thanks go to Svetlana Botnarenco and her family for the support provided during the 2015-smallholder-survey.

\section{References}

Adams Jr., R.H. 1991. The Economic Uses and Impact of International Remittances in Rural Egypt. Econ. Dev. Cult. Change 39, 695-722.

Adams Jr., R.H. 1998. Remittances, Investment, and Rural Asset Accumulation in Pakistan. Econ. Dev. Cult. Change 47, 155-173.

Aguilar-Støen, M., Taylor, M., Castellanos, E. 2016. Agriculture, Land Tenure and International Migration in Rural Guatemala. J. Agrar. Change 16, 123-144.

Alboiu, C., Kuliesis, G., Salengaite, D. 2011. The impact of Rural Development Program on Agriculture and Business/Rural Development in Lithuania and Romania: A Mirror Situation. Agricultural Economics and Rural Development, New Series VIII(1), 77-90.

Baumann, M., Kuemmerle, T., Elbakidze, M., Ozdugan, M., Radeloff, V.C., Keuler, N.S., Prishchepov, A.V., Kruhlov, I., Hostert, P. 2011. Patterns and Drivers of Post-Socialist Farmland Abandonment in Western Ukraine. Land Use Policy 28, 552-562.

Böhme, M.H. 2015. Does Migration Raise Agricultural Investment? An Empirical Analysis for Rural Mexico. Agr. Econ. 46, 211-225.

Bolganschi, D. 2011. Rural Out Migration and Land Use in Moldova. http://pdc.ceu.hu/archive/00006465/01/cps-research-report-rural-out-migration-moldova-2011.pdf [Accessed on 15 August 2017].

Chiodi, V., Jaimovich, E., Montes-Rojas, G. 2012. Migration, Remittances and Capital Accumulation: Evidence from Rural Mexico. J. Dev. Stud. 48, 1139-1155.

Cimpoieș, D. 2010. The economics of land fragmentation in the individual farm sector of Moldova. Ştiinţa Agricolă 2, 101-108.

Davidova, S., Thomson, K. 2013. Family farming: A Europe and Central Asia perspective. Draft background report for 'Regional dialogue on family farming: Working towards a strategic approach to promote food security and nutrition.' FAO, Brussels. http://www.fao.org/fileadmin/user_upload/Europe/documents/Events_2013/FF_EUCAP_en.pdf [Accessed on 14 September 2015].

Davis, J., Lopez-Carr, D. 2014. Migration, Remittances and Smallholder Decision-making: Implications for Land Use and Livelihood Change in Central America. Land Use Policy 36, 319-329. 
de Brauw, A., Rozelle, S. 2008. Migration and Household Investment in Rural China. China Econ. Rev. 19, 320-335.

Démurger, S., Fournier, M., Yang, W. 2010. Rural households' decisions towards income diversification: Evidence from a township in northern China. China Econ. Rev. 21(1), S32-S44.

Dessing, M. 2002. Labor Supply, the Family and Poverty: The S-shaped Labor Supply Curve. J. Econ. Behav. Organ. 49, 433-458.

European Council (EC). 2016. Council conclusions on the Republic of Moldova. http://www.consilium.europa.eu/en/press/press-releases/2016/02/15-fac-moldova-conclusions/ [Accessed on 15 September 2017].

European Union (EU). 2014. Association agenda between the European Union and the Republic of Moldova. http://eeas.europa.eu/archives/docs/moldova/pdf/eu-moldova-associationagenda-26_06_en.pdf [Accessed on 17 September 2017].

Food and Agriculture Organization of the United Nations (FAO). 2012. Assessment of the Agriculture and Rural Development Sectors in the Eastern Partnership Countries. The Republic of Moldova. http://www.fao.org/docrep/field/009/aq675e/aq675e.pdf [Accessed on $10 \mathrm{June}$ 2017].

Food and Agriculture Organization of the United Nations (FAO). 2014. The state of food and agriculture. Innovation in family farming. FAO, Rome, pp. xviii +139 .

Gorton, M., White, J. 2003. The politics of agrarian collapse: Decollectivisation in Moldova. E. Eur. Polit. Soc. 17(2), 305-331.

Gray, C.L. 2009. Rural Out-migration and Smallholder Agriculture in Southern Ecuadorian Andes. Popul. Environ. 30, 193-217.

Gray, C.L., Bilsborrow, R.E. 2014. Consequences of Out-migration for Land Use in Rural Ecuador. Land Use Policy 36, 182-191.

International Organization for Migration (IOM). 2016. Extended Migration Profile of the Republic of Moldova 2009-2014. Analytical report. http://www.iom.md/sites/default/files/publications/docs/EMP\%202009-2014\%20ENG.pdf [Accessed on 27 September 2017].

Jacoby, H.G. 1993. Shadow wages and peasant family labour supply: an econometric application to the Peruvian Sierra. Rev. Econ. Stud. 60, 903-921.

Kilic, T., Carletto, C., Miluka, J., Savastano, S. 2009. Rural Nonfarm Income and its Impact on Agriculture: Evidence from Albania. Agr. Econ. 40, 139-160.

Le, K.T. 2009. Shadow Wages and Shadow Income in Farmers' Labor Supply Functions. Am. J. Agr. Econ. 91, 685-696.

León-Ledesma, M., Piracha, M. 2004. International Migration and the Role of Remittances in Eastern Europe. Int. Migr. 42, 65-83.

Lerman, Z., Sutton, W.R. 2008. Productivity and efficiency of small and large farms in transition: Evidence from Moldova. Post-Sov. Aff. 24(2), 97-120.

Liu, G., Wang, H., Cheng, Y., Zheng, B., Lu, Z. 2016. The impact of rural out-migration on arable land use intensity: Evidence from mountain areas in Guangdong, China. Land Use Policy 59, 569-579.

Lücke, M., Omar Mahmoud, T., Steinmayr, A. 2009. Labour migration and remittances in Moldova: Is the boom over? Trends and preliminary findings from the IOM-CBSAXA panel 
household survey 2006-2008. https://www.econbiz.de/Record/labour-migration-remittances-moldova-boom-trends-preliminary-findings-iom-cbsaxa-panel-household-survey2006-2008-luecke-matthias/10008495216 [Accessed on 15 August 2017].

Macours, K., Swinnen, J.F.M. 2005. Agricultural Labor Adjustments in Transition Countries: The Role of Migration and Impact of Poverty. Rev. Agr. Econ. 27, 405-411.

Möllers, J., Herzfeld, T., Piras, S., Wolz, A. 2016. Structural Transformation of Moldovan Smallholder Agriculture: Implications for Poverty Reduction and Shared Prosperity. World Bank Group, Washington DC. http://www-wds.worldbank.org/external/default/WDSContentServer/WDSP/IB/2016/06/23/090224b0843f61cc/1_0/Rendered/PDF/Structural0tra0nd0shared0prosperity.pdf [Accessed on 15 August 2017].

Moroz, V., Stratan, A., Ignat, A., Lucasenco, E. 2015. Country Report: Republic of Moldova. http://www.agricistrade.eu/wp-content/uploads/2015/05/Agricistrade_Moldova.pdf [Accessed on 10 June 2017].

National Bureau of Statistics of the Republic of Moldova (NBS). 2011. General Agricultural Census 2011. National results, 1 Volume. http://www.statistica.md/public/files/publicatii_electronice/Recensamint_agricol/RGA_2011_date_definitive.pdf [Accessed on 15 August 2017].

National Bureau of Statistics of the Republic of Moldova (NBS). 2017a. Agricultural Activity of Small Agricultural Producers in the Republic of Moldova in 2014. http://www.statistica.md/public/files/Metadate/en/Mici_Producatori_Agricoli_en.pdf [Accessed on $15 \mathrm{Au}$ gust 2017].

National Bureau of Statistics of the Republic of Moldova (NBS). 2017b. Population Incomes and Expenditures (Household Budget Survey). http://www.statistica.md/public/files/Metadate/en/CBGC_en.pdf [Accessed on 15 August 2017].

National Bureau of Statistics of the Republic of Moldova (NBS). 2017c. Statistical Databank. http://statbank.statistica.md/pxweb/pxweb/en/?rxid=e4bd48c3-1a85-4f04-a2789d3960686388 [Accessed on 14 September 2017].

Pinger, P. 2010. Come Back or Stay? Spend Here or There? Return and Remittances: The Case of Moldova. Int. Migr. 48, 142-173.

Piras, S. 2016. Moldovan family farms: Social buffer or economic driver? A survey-based assessment. Doctoral dissertation, Università di Bologna.

Qin, H., Liao, T.F. 2016. Labor out-migration and agricultural change in rural China: A systematic review and meta-analysis. J. Rural Stud. 47, 533-541.

Rozelle, S. D., Taylor, J. E., de Brauw, A. 1999. Migration, Remittances, and Agricultural Productivity in China. Am. Econ. Rev. 89, 287-291.

Signoret, J.E. 2003. The Moldova HBS: A note on the panel sample. Unpublished internal document. World Bank Group, Washington DC.

Singh, I., Squire, L., Strauss, J. 1986. A Survey of Agricultural Household Models: Recent Findings and Policy Implications, World Bank Econ. Rev. 1, 149-179.

Skoufias, E. 1994. Using shadow wages to estimate labor supply of agricultural households. Am. J. Agr. Econ. 76, 215-227. 
Small, L.A. 2007. East Meets West: Utilising Western Literature to Conceptualise Post-Soviet Agrarian Change. J. Peasant Stud. 34(1): 29-50.

Stark, O. 1991. The Migration of Labor. Blackwell, Cambridge, MA, pp. $x+406$.

Sunam, R.K., McCarthy, J.F. 2016. Reconsidering the Links between Poverty, International Labour Migration, and Agrarian Change: Critical Insights from Nepal. J. Peasant Stud. 43, 39-63.

Swinnen, J.F.M., Dries, L., Macours, K. 2005. Transition and Agricultural Labor. Agr. Econ. 32, 15-34.

Taylor, J.E., Lopez-Feldman, A. 2010. Does Migration Make Rural Households More Productive? Evidence from Mexico. J. Dev. Stud. 46, 68-90.

Taylor, M.J., Aguilar-Støen, M., Castellanos, E., Moran-Taylor, M.J., Gerkin, K. 2016. International Migration, Land Use Change and the Environment in Ixcán, Guatemala. Land Use Policy 54, 290-301.

Vargas-Lundius, R., Lanly, G., Villarreal, M., Osorio, M. 2002. International Migration, Remittances and Rural Development: Enabling Poor Rural People to Overcome Poverty. http://www.msu.ac.zw/elearning/material/1330864645Reading\%204\%20International\%20migration.docx [Accessed on 15 August 2017].

World Bank (WB). 2015. Moldova Public Expenditure Review: Agriculture. World Bank Group, Washington DC. https://openknowledge.worldbank.org/handle/10986/28331 [Accessed on 15 September 2017].

World Bank (WB). 2017. World Bank Open Data. http://data.worldbank.org/ [Accessed on 15 August 2017]. 